Wilhelm, S. I., S. M. Dooley, E. P. Corbett, M. G. Fitzsimmons, P. C. Ryan, and G. J. Robertson. 2021. Effects of land-based light pollution on two species of burrow-nesting seabirds in Newfoundland and Labrador, Canada. Avian Conservation and Ecology 16(1):12. https://doi.org/10.5751/ ACE-01809-160112

Copyright $(\mathcal{C} 2021$ by the author(s). Published here under license by the Resilience Alliance.

Research Paper

\title{
Effects of land-based light pollution on two species of burrow-nesting seabirds in Newfoundland and Labrador, Canada
}

Sabina I. Wilhelm ${ }^{1}$, Suzanne M. Dooley ${ }^{2}$, Emma P. Corbett ${ }^{2}$, Michelle G. Fitzsimmons $^{3}$, Pierre C. Ryan ${ }^{1}$ and Gregory J. Robertson $^{3}$ ${ }^{1}$ Canadian Wildlife Service, Environment and Climate Change Canada, Mount Pearl, NL, Canada, ${ }^{2}$ Canadian Parks and Wilderness Society - Newfoundland and Labrador Chapter, St. John's, NL, Canada, ${ }^{3}$ Wildlife Research Division, Environment and Climate Change Canada, Mount Pearl, NL, Canada

ABSTRACT. This study examines the occurrence and underlying factors of onshore strandings of two species of seabirds breeding in Newfoundland and Labrador, Canada. Atlantic Puffins (Fratercula arctica) are found stranded in coastal communities bordering the Witless Bay Ecological Reserve in artificially lit areas. Between 2011 and 2020, 3845 recently fledged puffins were found during nightly searches. Counts of puffins found per night were related to the phase of the moon, with the fewest birds found around the full moon. Mean annual body mass of pufflings was positively associated with annual recovery rates, providing a non-intrusive approach to monitor inter-annual productivity at the colony. Using two approaches to estimate population impacts of strandings, we estimate that $<0.2 \%$ of fledging chicks were attracted to lights emitted from coastal communities. Despite bordering two of the largest Leach's Storm-Petrel (Oceanodroma leucorhoa) colonies in Newfoundland, this species was rarely observed stranded in the Witless Bay area. Rather, most of the 1903 stranded storm-petrels reported in 2018 and 2019 were found on industrial properties bordering, or inland of, Conception Bay, at minimal distances of $25 \mathrm{~km}$ inland from the Witless Bay Ecological Reserve. Most storm-petrels were recently fledged juveniles. Strandings were less likely to occur around the full moon. Neither strong nor persistent winds were observed during nights of large stranding events, however, these nights tended to have winds coming from the north, suggesting that stranded storm-petrels fledged from Baccalieu Island, located at the mouth of Conception Bay and hosting the largest colony in the world. Stronger mitigation measures to avoid and minimize light emittance, as well as research investigating light characteristics to reduce attraction, are urgently needed to decrease unnecessary strandings, particularly for the Leach's Storm-Petrel, recently assessed as Threatened by the Committee on the Status of Endangered Wildlife in Canada.

\section{Effets de la pollution lumineuse terrestre sur deux espèces d'oiseaux marins nichant dans des terriers en Terre-Neuve-et-Labrador, Canada}

RÉSUMÉ. Cette étude porte sur l'occurrence et les facteurs sous-jacents l'échouement terrestre de deux espèces d'oiseaux marins nichant en Terre-Neuve-et-Labrador, au Canada. Les Macareux moines (Fratercula arctica) sont retrouvés échoués dans des communautés côtières bordant la réserve écologique de Witless Bay, aux endroits éclairés artificiellement. Entre 2011 et 2020 , 3845 macareux ayant récemment pris leur envol ont été trouvés lors de recherches nocturnes. Le nombre de macareux trouvés par nuit était lié à la phase de la lune; il était à son minimum autour de la pleine lune. La masse corporelle annuelle moyenne des jeunes macareux était positivement associée au taux de récupération annuel, fournissant une approche non-intrusive pour surveiller la productivité interannuelle de la colonie. Au moyen de deux approches pour estimer les impacts des échouements sur la population, nous avons calculé que $<0,2 \%$ des jeunes à l'envol ont été attirés par les lumières émises par les communautés côtières. Bien que deux des plus grandes colonies d'Océanites cul-blanc (Oceanodroma leucorhoa) de Terre-Neuve se trouvent dans la région de Witless Bay, cette espèce y a rarement été trouvée échouée. Au contraire, la plupart des 1903 océanites échoués signalés en 2018 et 2019 ont été trouvés sur des propriétés industrielles bordant la baie Conception ou à l'intérieur des terres, à des distances minimales de $25 \mathrm{~km}$ de la réserve écologique de Witless Bay. La plupart des océanites étaient des jeunes ayant récemment pris leur envol. Les échouements étaient moins susceptibles de se produire autour de la pleine lune. Aucun vent fort ou persistant n'a été observé au cours des nuits d'échouements importants, mais des vents venant du nord soufflaient durant ces nuits, donnant à penser que les océanites échoués avaient pris leur envol de l'île Baccalieu, située à l'embouchure de la baie Conception et abritant la plus grande colonie au monde. Il est de toute urgence nécessaire d'appliquer des mesures d'atténuation plus strictes pour éviter et minimiser l'émission de lumière, et de faire des recherches sur les caractéristiques de la lumière pour en réduire l'attraction, afin de diminuer les échouements inutiles, en particulier pour l'Océanite culblanc, qui vient de se voir attribuer le statut de «menacé » par le Comité sur la situation des espèces en péril au Canada.

Key Words: attraction; coastal; impact; light pollution; onshore; seabird; stranding

Address of Correspondent: Sabina I. Wilhelm, Canadian Wildlife Service, Environment and Climate Change Canada, Mount Pearl, NL, Canada, sabina.wilhelm@canada.ca 


\section{INTRODUCTION}

Light pollution is rapidly increasing, resulting in global alterations to the natural environment and threatening biodiversity on land and sea (Cinzano et al. 2001, Depledge et al. 2010, Hölker et al. 2010, Falchi et al. 2016). Artificial lights can have fatal consequences to seabirds, particularly fledglings of burrow-nesting species (reviewed in Rodríguez et al. 2017b). Fledglings attracted to shore are at risk of collisions with a variety of lit structures, and grounded fledglings are in danger of depredation, vehicle collisions, or exposure (Rodríguez et al. 2012, 2014). Globally, light attraction appears to affect primarily burrow-nesting petrels (Rodríguez et al. 2017b). However, in coastal communities bordering the Witless Bay Ecological Reserve, Newfoundland and Labrador, Canada, the Atlantic Puffin (Fratercula arctica; hereafter, puffin) is the most commonly found stranded species during the fledging period (Wilhelm et al. 2013). Adult puffins are diurnal at the colony, however, like other burrow-nesting species, the young have adapted to fledge at night to avoid predation (Harris and Birkhead 1985). Atlantic Puffins are identified as Vulnerable on the International Union for Conservation of Nature (IUCN) Red List (BirdLife International 2018a). The Witless Bay Ecological Reserve protects the largest concentration of breeding puffins in North America ( 304,000 breeding pairs; Wilhelm et al. 2015, Wilhelm 2017).

In addition to protecting important puffin populations, the Witless Bay Ecological Reserve is also host to internationally significant Leach's Storm-Petrel (Oceanodroma leucorhoa; hereafter, storm-petrel) colonies ( 314,000 pairs; Wilhelm et al. 2015, Wilhelm 2017). Storm-petrels are active at breeding colonies only at night; fledglings are similar in size as adults and are selfsufficient once they leave the colony (Pollet et al. 2020). Leach's Storm-Petrels are also identified as Vulnerable on the IUCN Red List (BirdLife International 2018b). Furthermore, because of significant population declines at major colonies on Newfoundland's east coast, including the Witless Bay Ecological Reserve and Baccalieu Ecological Reserve (Wilhelm et al. 2015, Wilhelm 2017, Wilhelm et al. 2020), the Committee on the Status of Endangered Wildlife in Canada has recently assessed the Atlantic population of Leach's Storm-Petrel as Threatened (https://www.cosewic.ca/index.php/en-ca/news-and-events/pressrelease-november-2020).

Since 2011, the Canadian Parks and Wilderness Society Newfoundland and Labrador Chapter (CPAWS-NL), a not-forprofit organization, oversees a puffin and storm-petrel rescue campaign. Every August CPAWS-NL coordinates hundreds of volunteers who conduct nightly searches for recently fledged stranded puffins in communities bordering the Witless Bay Ecological Reserve, providing safe overnight storage of captured birds and coordinating their release the following morning (Wilhelm et al. 2013). The rescue campaign also includes stormpetrels, and the public is encouraged to report any sightings of stranded storm-petrels throughout their fledging period from September to November.

Rescue efforts are effective at directly reducing mortality associated with light attraction, but tend to lack the ability to evaluate whether stranded birds are representative of the population from which they came and what impact strandings have on populations (Rodríguez et al. 2017b,c). Furthermore, little is known about environmental factors that influence strandings in these two species. A previous study based on one season found that most puffin strandings occurred around the new moon (Wilhelm et al. 2013), a phenomenon also observed in other species that fledge at night (Verheijen 1981, Telfer et al. 1987, Le Corre et al. 2002, Rodríguez and Rodríguez 2009, Rodríguez et al. 2014, Rodríguez et al. 2016, Cianchetti-Benedetti et al. 2018). Leach's Storm-Petrels have been reported being pushed onshore following gales and storms during their migration (Teixeira 1987, Pollet et al. 2020), but these observations remain largely anecdotal.

We present the results of ten years of data to investigate the annual variability in the number of stranded recently fledged puffins found and the influence of the phase of moon on stranding numbers. We compare annual variability in body mass and wing length of stranded fledglings to that of a random sample of puffin chicks captured and measured at the colony over three breeding seasons, and test the idea that the annual number of puffins found stranded is related to chick production at the colony. We also estimate the proportion of puffins fledging from colonies in the Witless Bay Ecological Reserve affected by light attraction through banding and reproductive success studies conducted in 2019. In addition, we provide the first overview of the spatial distribution and relative magnitude of storm-petrels stranded in eastern Newfoundland based on information collected in 2018 and 2019, investigate annual variability in body mass and wing length of fledglings, and discuss stranding results in relation to environmental conditions and light attraction.

\section{METHODS}

\section{Study area}

The Witless Bay Ecological Reserve, Newfoundland and Labrador, Canada $\left(47^{\circ} 11^{\prime}-47^{\circ} 16^{\prime} \mathrm{N}\right.$ and $\left.52^{\circ} 46^{\prime}-52^{\circ} 49^{\prime} \mathrm{W}\right)$ is located on the east coast of Newfoundland's Avalon Peninsula, and was established to protect four islands hosting nationally and globally significant seabird colonies (Government of Newfoundland and Labrador 1994). The islands within the Reserve are close to shore $(<3 \mathrm{~km}$ to nearest shoreline $)$ and border seven small communities (each $<2,000$ residents; Statistics Canada 2016) in which nightly searches for stranded puffins occur during the fledging period: Bay Bulls $\left(47^{\circ} 19.1^{\prime} \mathrm{N}, 52^{\circ} 48.9^{\prime} \mathrm{W}\right)$, Witless Bay $\left(47^{\circ} 16.85^{\prime} \mathrm{N}, 52^{\circ} 49.4^{\prime} \mathrm{W}\right)$, Mobile $\left(47^{\circ} 14.7^{\prime} \mathrm{N}, 52^{\circ}\right.$ $\left.50.4^{\prime} \mathrm{W}\right)$, Tors Cove $\left(47^{\circ} 13^{\prime} \mathrm{N}, 52^{\circ} 51.1^{\prime} \mathrm{W}\right)$, Burnt Cove $\left(47^{\circ} 12^{\prime} \mathrm{N}\right.$, $\left.52^{\circ} 50^{\prime} \mathrm{W}\right)$, St. Michael's $\left(47^{\circ} 11.6^{\prime} \mathrm{N}, 52^{\circ} 50.7^{\prime} \mathrm{W}\right)$ and Bauline South ( $47^{\circ} 10.8^{\prime} \mathrm{N}, 52^{\circ} 50.7^{\prime} \mathrm{W}$; Wilhelm et al. 2013). Colony-based information was collected from Gull Island $\left(47^{\circ} 15.7^{\prime} \mathrm{N}, 52^{\circ}\right.$ $\left.46.4^{\prime} \mathrm{W}\right)$, the second largest puffin colony in the Witless Bay Ecological Reserve ( 118,000 pairs, Wilhelm 2017).

Reports of stranded storm-petrels collected during the species' fledging period in 2018 and 2019 came from across the island of Newfoundland, but occurred mostly along the shores of Conception Bay, a principal bay of Newfoundland's Avalon Peninsula bordering the densely populated St. John's metropolitan area (205,955 residents, including surrounding subdivisions; Statistics Canada 2016). In 2018 and 2019, stormpetrel carcasses were collected at four industrial sites in possession of a Environment and Climate Change Canada - Canadian Wildlife Service (ECCC-CWS) permit: a thermal power 
generating station in Holyrood $\left(47^{\circ} 27.2^{\prime} \mathrm{N}, 52^{\circ} 5.8^{\prime} \mathrm{W}\right)$, a converter station at Soldier's Pond located within the city limits of St. John's $\left(47^{\circ} 25.1^{\prime} \mathrm{N}, 52^{\circ} 58.8^{\prime} \mathrm{W}\right)$, a seismic survey vessel docked in Bay Bulls $\left(47^{\circ} 19.1^{\prime} \mathrm{N}, 52^{\circ} 48.8^{\prime} \mathrm{W}\right)$, and a fabrication site for the offshore oil industry in Argentia, Placentia Bay $\left(47^{\circ} 18.1^{\prime} \mathrm{N}, 53^{\circ}\right.$ 59.3'W); carcasses were also collected at a fish plant in Bay de Verde $\left(48^{\circ} 5.3^{\prime} \mathrm{N}, 52^{\circ} 53.7^{\prime} \mathrm{W}\right)$.

\section{Collection of information on stranded birds} Atlantic Puffins

The rescue campaign, coordinated by CPAWS-NL since 2011, recruits volunteers through various local and web-based outreach efforts to conduct nightly searches (between $9 \mathrm{pm}$ and $2 \mathrm{am}$ ) for live and dead puffins throughout the fledgling period (August to early September). Volunteers register in person with CPAWS-NL at the rescue campaign headquarters located in Bay Bulls, receive training on bird handling as well as a copy of an ECCC-CWS scientific permit allowing them to be in temporary possession of a migratory bird, and borrow appropriate personal protective equipment (i.e., reflective vests, flashlights, crates, butterfly nets). Due to the popularity of the program, since 2018, volunteers book online the nights they wish to patrol, to avoid an excessive number of patrollers on any given night. Once equipped, volunteers search the communities either by car or by foot; live puffins are captured using a butterfly net and/or by hand, placed in a ventilated crate, and brought back to headquarters where birds are kept overnight. Dead birds are also brought back to headquarters and provided to ECCC-CWS employees the following morning. In recent years, volunteers are also asked to provide information on where birds were found, with the most comprehensive dataset available for 2019. The following morning, birds are banded with a metal United States Fish and Wildlife Service band, weighed with a 500g Pesola spring scale, and their right flattened wing is measured to the nearest $\mathrm{mm}$ using a wing ruler. Puffins are subsequently released either from a beach in Witless Bay or from a boat near Gull Island. Birds are only released when no gulls are present in the area and moved to a different release site when gulls are observed.

\section{Leach's Storm-Petrels}

Scientific permit holders at two industrial sites located in Soldier's Pond and Argentia conducted daily searches (beginning in 2017 and 2018, respectively) to collect stranded storm-petrels throughout the fledging period and reported all strandings to ECCC-CWS. Employees at the Holyrood site also began conducting daily searches to collect stranded birds following a mass stranding event observed on the night of 8 October 2018. Daily monitoring of stranded birds was resumed during the storm-petrel fledging period in 2019 at all three sites. In 2018 and 2019, ECCC-CWS and CPAWS-NL received additional reports of stranded storm-petrels from the public from across the Avalon Peninsula, recorded the date and location of each stranding, collected dead storm-petrels, and instructed the public to release live birds at dusk at a coastal site close to their location.

A total of 643 dead birds were brought to or collected by ECCCCWS in 2018 and 2019 and were examined to confirm age class (fledglings were differentiated from adults by their darker feather coloration and pointy primary tips; Pyle 2008), obtain body mass
(Sartorius electronic scale recorded to the nearest g), and flattened wing length (within $1 \mathrm{~mm}$ ) using a wing ruler (note that we only measured non-scavenged storm-petrels; $\mathrm{N}=524$ ). In addition, 43 live birds found stranded in Bay de Verde on 2 and 3 October 2019 were examined prior to their release at dusk; birds were aged using the same criteria as above and measured using a 100-g Pesola spring scale $( \pm 1 \mathrm{~g})$ and a wing ruler.

\section{Communities and property types}

We summarized by community in which stranded birds were found, based on the information provided by the reporter, and classified the type of property on which stranded puffins (2019) and storm-petrels (for 2018 and 2019) were found into the following eight categories: 1) airport, 2) business (e.g., retail store, grocery store, restaurant, hotel or other small business), 3) government (i.e., municipal, provincial or federal-operated property), 4) outdoor recreational (e.g., beach, sports field), 5) other public property (e.g., school, church), 6) industry (e.g., fish/ crab processing plant, energy producing plant, water treatment plant, tank farms), 7) residential, and 8) road or highway.

\section{Moon phase and wind data}

Data associated with the eight phases of the moon (new moon, waxing crescent, first quarter, waxing gibbous, full moon, waning gibbous, last quarter, and waning crescent), and the moon's age (0-29 days) were obtained from https://www.almanac.com/ astronomy/moon/calendar.

Wind data were obtained from a weather station located in St. John's West $\left(47^{\circ} 30^{\prime} \mathrm{N}, 52^{\circ} 47^{\prime} \mathrm{W}\right.$; https://climate.weather.gc.ca/ climate_data/hourly_data_e.html), approximately $18 \mathrm{~km}$ and 20 $\mathrm{km}$ from the Soldier's Pond and Holyrood sites, respectively. Mean nightly wind speed $(\mathrm{km} / \mathrm{hr})$ and direction $\left(0-360^{\circ}\right)$ were calculated from hourly data collected between 17:30 to 6:30 the following morning, corresponding to 1 hour after sunset and a half hour before sunrise. Mean nightly wind direction was subsequently categorized into one of the eight cardinal and inter-cardinal directions (N, NE, E, SE, S, SW, W, NW).

\section{Colony-based puffin information}

We assessed the reproductive success of puffins on Gull Island in 2019 by initially marking 50 burrows that contained an egg on 28 and 31 May (median lay date = 26-27 May; Rodway et al. 1998). Five burrows were not relocated in subsequent visits and therefore were removed from the sample. A subsequent check on 14 July 2019 was made to determine whether chicks had hatched, as eggs hatch 39-43 days after being laid (Harris and Wanless 2011). Burrows were then checked every 2-3 days until September to determine fledging success, inferred from age and body mass, and wing length during the last visit.

To estimate the proportion of puffins fledging from colonies potentially affected by light attraction, we banded a total of 497 puffin chicks on the west side of Gull Island between 7 and 16 August 2019, and 609 chicks on the east side of Gull Island between 15 and 21 August 2019. Chicks were taken from randomly chosen burrows which were sufficiently short to gently remove the chick by hand.

We measured chicks at the colony to examine how mean annual body mass of stranded pufflings compared to that of chicks at 
the colony. Field work occurred on Gull Island on 15 August 2017, 15-20 August 2018, and 12-15 August 2019. Chicks were gently taken out of their burrow by hand, placed in a cotton bag, weighed using a 500-g Pesola spring scale, the right flattened wing length measured $(\mathrm{mm})$ using a wing ruler, banded with a metal US Fish and Wildlife Service band, and placed back into their burrow. In 2017 and 2018, a total of 28 and 58 chicks, respectively, were measured from the west side of the island which faces the community of Witless Bay. In 2019, 23 chicks were measured from the west side and 26 chicks from the east side of the island, which faces the open ocean. These chicks were included in the banded sample described above.

$\underline{\text { Statistical analyses }}$

\section{Atlantic Puffins}

Since the number of puffins found each year varied and there was a clear seasonal pattern of when they arrived onshore, these two factors needed to be addressed before an analysis with moon phase could be conducted. The underlying data are counts of puffins found on each day from 6 August to 6 September, which ranged from 0 (40.3\% of observations) to a maximum of 123 . Due to the large number of zeroes in the counts and clear overdispersion (more variation than expected from Poisson process, mean $=11$, variance $=382$ ) zero-inflated negative binomial models were fit using the $p s c l$ package (Zeileis et al. 2008) in R 3.6.3 (R Core Team 2020). To account for the seasonal pattern in numbers found ashore, a quadratic function on day of year was included in the model, and to account for annual differences in the number coming to shore, a fixed categorical effect of year was included; these terms were included to model both the count and binomial process. This model essentially fit a humped-shaped curve peaking at the same time of year, but deferring in height depending on whether few or many puffins arrived on shore in that year. To assess the potential effect of moon phase, moon phase was added as a fixed categorical effect to the model, and compared to the base model with a standard likelihood ratio test. All of these models produced similar fits with seasonal peaks, but had higher AIC values than the final zero-inflation negative binomial model used, and adding moon phase to any of these models improved model fit. Therefore, we feel our overall conclusion about moon phase is robust to whichever model is used to model the seasonal peaks and annual differences in numbers of puffins coming to shore.

We used linear and simple non-linear modeling (using $1 \mathrm{~m}$ and nls in R 3.6.3 [R Core Team 2020]) with normally distributed errors to examine annual variation in body mass of stranded puffins. To test the idea that numbers of puffins found stranded is related to chick production at the colony, we investigated whether the mass of stranded puffins was related to the number found; good production years should produce many chicks at heavier masses, while poor years should produce few chicks with low masses. We fit a linear model and a range of non-linear decelerating functions, reflecting that body mass of chicks cannot increase indefinitely, so at some number of stranded puffins we would not expect annual body mass to continue to increase. We found the best fit function (compared with AIC values) was a simple regression with natural logarithm of numbers of stranded puffins as the predictor (Pinheiro et al. 2020). For chicks measured at the colony across a range of dates and ages during the growth period, we analyzed body mass controlling for chick age (using wing length as in Rodway 1997) using a linear model with year $(2017,2018$, and 2019) as a factor, wing length as a covariate and the interaction of these variables (i.e., ANCOVA). A similar analysis was conducted to assess whether puffin chick mass controlling for chick age was different on the east and west-facing sides of Gull Island in 2019.

To assess the proportion of puffin fledglings potentially affected by light attraction, we assessed what proportion of chicks banded at the colony were found by rescue efforts in 2019 . The proportion of puffin fledglings potentially affected by light attraction was also assessed through an approach adapted by Rodríguez and Rodríguez (2009), which is simply the number of chicks found by rescue efforts divided by the number of fledglings produced by the colony (estimated as the total breeding population size multiplied by the breeding success of the colony). A basic resampling approached was used to estimate error in the number of chicks produced at the colony: 100,000 binomial samples of breeding success based on monitored burrows was multiplied by 100,000 samples of a normal distribution of population size of breeding pairs in the Witless Bay Ecological Reserve (304,000 pairs with a coefficient of variation of $7.8 \%$; Wilhelm et al. 2013, 2015, Wilhelm 2017).

Leach's Storm-Petrels

We applied a two-way ANOVA to investigate differences in mean annual mass and wing length between years (2018 and 2019) and location (Bay de Verde and Holyrood).

Values are reported as means \pm 1 SD unless otherwise noted.

\section{RESULTS}

\section{Atlantic Puffins}

Between 2011 and 2020, 3845 recently fledged puffins were found stranded along the coast between Bay Bulls and Bauline South, communities bordering the Witless Bay Ecological Reserve; annual counts ranged from 18 to 812 puffins (Table 1). The majority of stranded pufflings $(93 \%)$ were found alive and successfully released (Table 1); very few individuals had to be euthanized due to injury. The communities in which puffins were found was documented for 214 birds in 2019. Of these, the property on which puffins were found was documented for 77 birds. Most stranded puffins were found in the community of Witless Bay (87\%), followed by Bauline South (6\%). Recently fledged puffins were also found within the municipal limits of Bay Bulls $(2 \%)$, Mobile (<1\%), Tors Cove (3\%), and Burnt Cove/St. Michael's ( $1 \%$;). Most of these were found on industrial $(35 \%)$, business properties $(29 \%)$, or roads $(25 \%)$. The remaining stranded puffins were found at other public buildings $(5 \%)$, residential $(4 \%)$, or outdoor recreational properties $(3 \%)$.

Pooling all years, puffins stranded between 6 August and 6 September with a median date of 19 August (Fig. 1). Moon phase explained significant variation in the numbers of puffins found (LRT, $\mathrm{X}_{7}^{2}=106.5, \mathrm{p}<0.0001$; Fig. 2), with the fewest birds found around the full moon, even after accounting for seasonal peaks and annual differences in numbers found. 
Table 1. Number of recently fledged Atlantic Puffins (Fratercula arctica) found through efforts of the rescue campaign in communities bordering the Witless Bay Ecological Reserve from 2011 to 2020 .

\begin{tabular}{lcccc}
\hline \hline Year & $\begin{array}{c}\text { No. banded } \\
\text { and released }\end{array}$ & $\begin{array}{c}\text { Additional } \\
\text { found alive } \\
\text { and released }\end{array}$ & $\begin{array}{c}\text { Additional } \\
\text { found dead } \\
\text { or were } \\
\text { euthanized }\end{array}$ & Total \\
\hline 2011 & 3 & 10 & 5 & 18 \\
2012 & 388 & 29 & 82 & 499 \\
2013 & 61 & 12 & 3 & 76 \\
2014 & 728 & 31 & 53 & 812 \\
2015 & 242 & 6 & 7 & 255 \\
2016 & 111 & 0 & 10 & 121 \\
2017 & 730 & 0 & 29 & 759 \\
2018 & 551 & 0 & 22 & 573 \\
2019 & 300 & 0 & 26 & 326 \\
2020 & 387 & 1 & 18 & 406 \\
Total & 3501 & 89 & 255 & 3845 \\
\hline \multicolumn{5}{r}{}
\end{tabular}

Fig. 1. Mean ( \pm SD) counts of Atlantic Puffin (Fratercula arctica) fledglings found stranded across the fledging period, all years combined (2011-2020). Mean counts include zeroes (i.e., nights when no stranded birds were found).

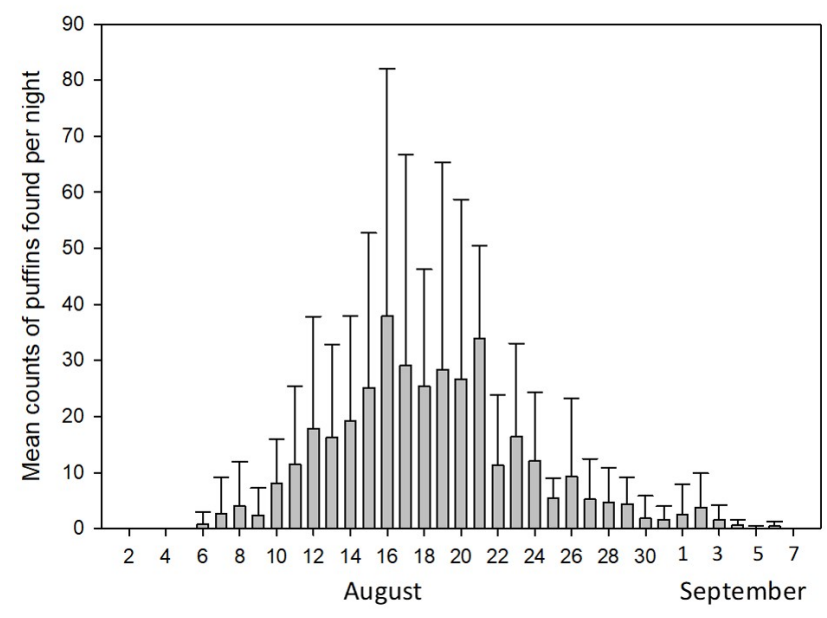

Mean annual body mass of fledglings varied significantly across years $\left(\mathrm{F}_{9,3491}=89.57, \mathrm{p}<0.001\right)$, ranging between $210 \mathrm{~g}(2011)$ and $279 \mathrm{~g} \mathrm{(2017)}$ with an overall mean annual mass of $253 \pm 22$ $\mathrm{g}(\mathrm{N}=10$; Fig. 3). The body mass of puffins increased, but decelerated, as the number of stranded puffins found each year increased (regression of $\ln$ (number stranded) on body mass, $F_{1}$, ${ }_{3499}=483.3, \mathrm{p}<0.0001$; Fig. 4). Similarly, chicks measured at the colony in 2017 were heavier in relation to their body size compared to 2018 and $2019\left(\mathrm{t}_{178}=11.3\right.$ and $\mathrm{t}_{178}=12.0$ respectively, $\mathrm{p}<$ 0.001 ), while there was no evidence of a difference between 2018 and $2019\left(\mathrm{t}_{178}=0.15, \mathrm{p}<0.99\right.$, Fig. 5).
Fig. 2. Mean number of stranded Atlantic puffin (Fratercula arctica) fledglings found per night $( \pm 95 \% \mathrm{CI})$ from $2011-2020$, in relation to the eight moon phases, and controlling for seasonal patterns and annual differences (see Methods for details).

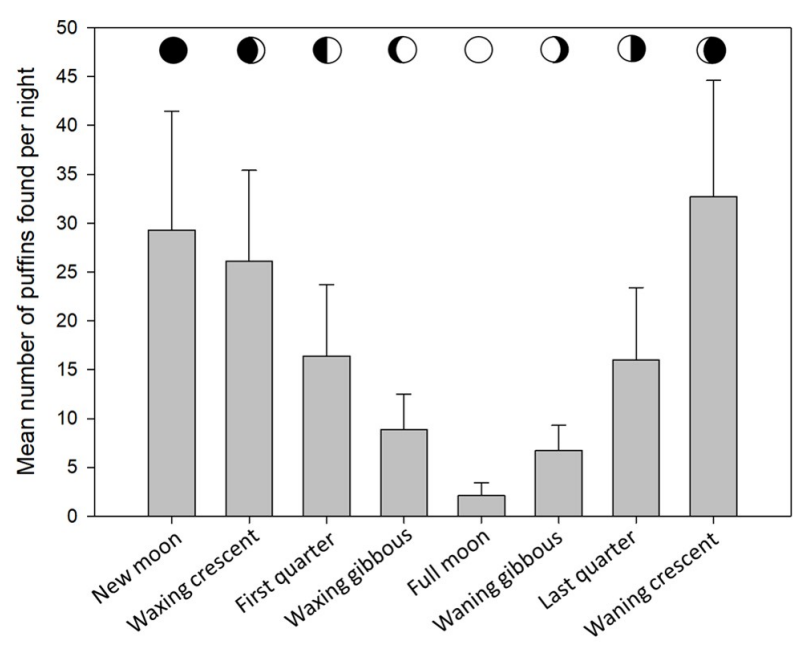

Fig. 3. Body mass of stranded Atlantic Puffin (Fratercula arctica) fledglings captured and released between 2011 and 2020. Data presented in box plots (black line as median, box as interquartile range, whiskers as min-max values, and black dots as outliers). Solid horizontal bar represents the 10 -year mean annual mass $(253 \mathrm{~g})$.

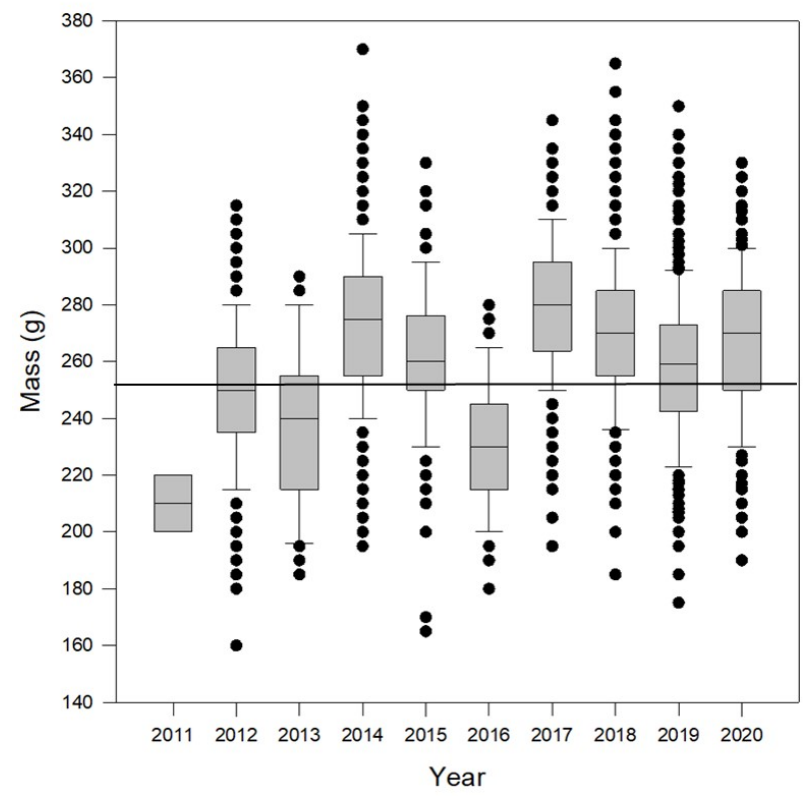


Fig. 4. Mean annual mass ( \pm SD) of stranded Atlantic Puffin (Fratercula arctica) fledglings captured and released in relation to the total number of fledglings found (live and dead) in each year.

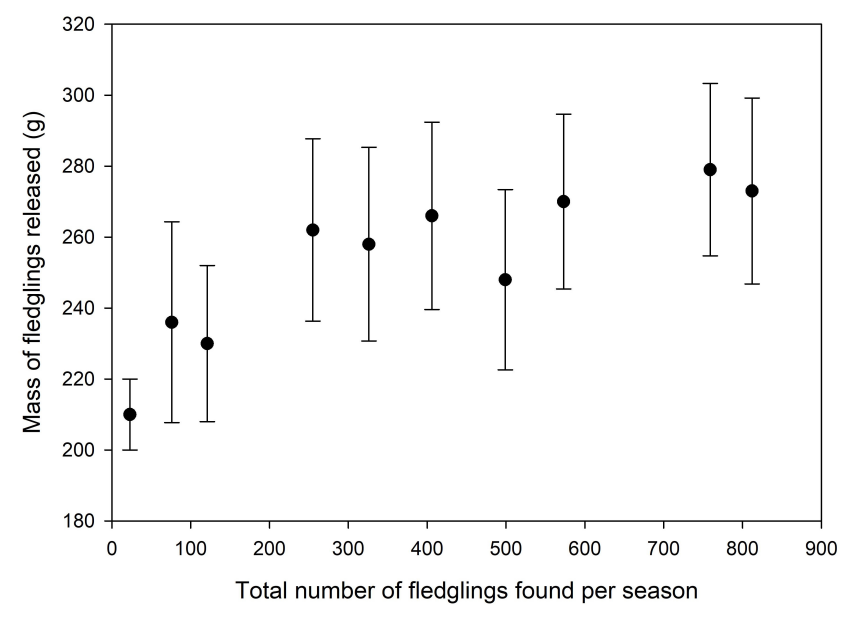

Fig. 5. Body mass relative to wing length of Atlantic Puffin (Fratercula arctica) chicks measured on Gull Island in 2017-2019.

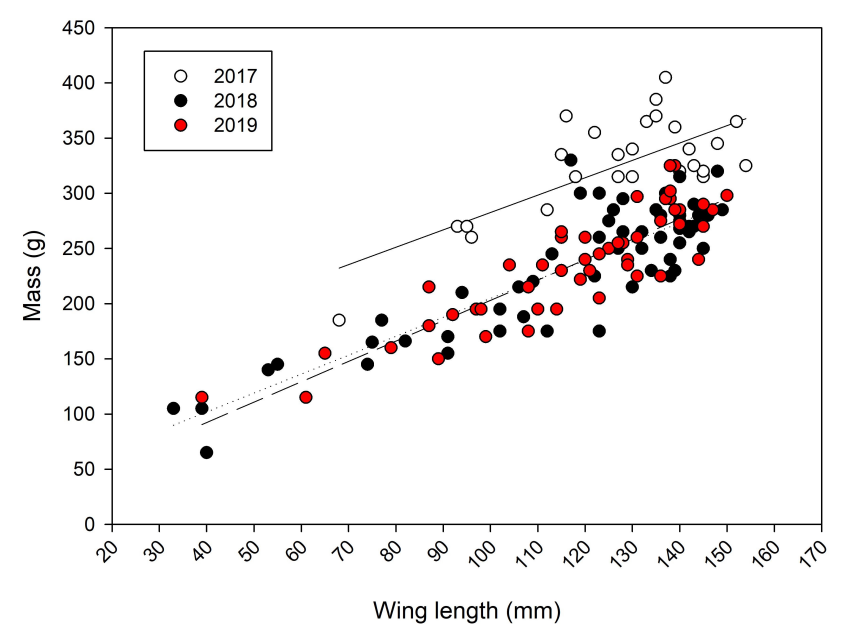

Two pufflings banded on Gull Island in August 2019 were subsequently recovered during the rescue campaign's nightly searches. The first was found during the night of 23 August; the exact location is unknown as it was only noticed that the puffin was already banded the following morning at the beach prior to its release. This individual was banded on 12 August on the west side of Gull Island, which faces the coastal community of Witless Bay. The second individual was found during the night of 29 August in the community of Witless Bay, at a convenience store located on the main road along the coast of Witless Bay. This puffling was also banded on 12 August on the west side of Gull
Island. These two recoveries from a total of 1106 chicks banded at the colony suggest that a minimum of $0.18 \%$ (95\% CI: $0.045 \%$ $-0.72 \%$ ) of puffins fledging from Gull Island were impacted by lights emitted from the communities.

The hatching success rate for puffins breeding on Gull Island in 2019 was 0.89 ( 40 of 45 eggs monitored hatched) and the fledging success rate of chicks was 0.95 (38 of 40 chicks monitored fledged), representing an overall reproductive success rate of $0.844 \pm 0.054$. Based on this value, we estimate that 246,069 $\pm 25,988$ fledglings departed the colonies in the Witless Bay Ecological Reserve in 2019. The rescue campaign recovered 326 individuals in 2019 (Table 1), suggesting that a minimum of $0.13 \%$ (95\% CI: $0.11 \%-0.17 \%$ ) of fledglings produced in 2019 were impacted by lights emitted from the communities.

\section{Leach's Storm-Petrels}

We received reports of 1156 stranded Leach's Storm-Petrels in 2018 and 747 in 2019 (Table 2). The earliest report of a stranded storm-petrel during the species' fledging period was received on 19 September 2018 and the latest on 17 November 2018, with the majority of stranded storm-petrels reported throughout October in both years $(2018=96 \%, 2019=87 \%$; Table 2$)$. The proportion of stranded birds found alive was 40\% in 2018 and 60\% in 2019 (Table 2).

Table 2. Number and status (alive or dead) of reported Leach's Storm-Petrels (Oceanodroma leucorhoa) stranded in Newfoundland in 2018 and 2019.

\begin{tabular}{lccccccc}
\hline \hline & \multicolumn{3}{c}{2018} & & & \multicolumn{3}{c}{2019} \\
\cline { 2 - 4 } \cline { 7 - 8 } \cline { 7 - 8 } & Alive & Dead & Total & & Alive & Dead & Total \\
\hline September & 9 & 30 & 39 & & 74 & 16 & 90 \\
October & 452 & 661 & 1113 & & 363 & 284 & 647 \\
November & 4 & 0 & 4 & & 8 & 2 & 10 \\
Total & 465 & 691 & 1156 & & 445 & 302 & 747 \\
\hline
\end{tabular}

Reports of stranded storm-petrels were received from residents living in 13 municipalities from across Newfoundland in 2018 with reports expanding to 22 municipalities in 2019 . The vast majority $(97 \%)$ of stranding reports came from Newfoundland's northern Avalon Peninsula, with hotspots identified along the northwest tip and southeast coast of Conception Bay (Fig. 6). Information on the type of property where strandings occurred was available for 1815 storm-petrels (2018 and 2019 combined) and revealed that $89 \%$ of strandings were reported on 6 industry properties, $6 \%$ on business properties, and $3 \%$ on roads or highways; other types of properties (airport, outdoor recreational sites, public buildings, or residential) each represented $1 \%$ or less of reported strandings.

We aged a total of 552 storm-petrels in 2018 from four industry sites (Holyrood, Soldier's Pond, Bay de Verde and Argentia); all were aged as recently fledged birds, except for one adult recovered at the Holyrood site. In 2019, we aged 134 stranded birds from five industry sites (Holyrood, Soldier's Pond, Bay de Verde, Bay Bulls, and Argentia), all of which were aged as fledglings, except for four individuals. Three of the four adults were found on a seismic vessel that had been docked in Bay Bulls for five days before the strandings occurred, and the other adult was recovered at the Bay de Verde fish plant. 
Fig. 6. Distribution and abundance of stranded Leach's StormPetrels (Oceanodroma leucorhoa) across insular Newfoundland's Avalon Peninsula reported during the species' fledging season by the public and scientific permit holders in 2018 and 2019 combined. Also shown are Newfoundland's three largest Leach's Storm-Petrel colonies: Baccalieu Island (2 million pairs), Gull Island (180,000 pairs) and Great Island (134,000 pairs; Wilhelm et al. 2015, Wilhelm 2017, Wilhelm et al. 2020). Red circles refer to five industry sites where carcasses were collected.

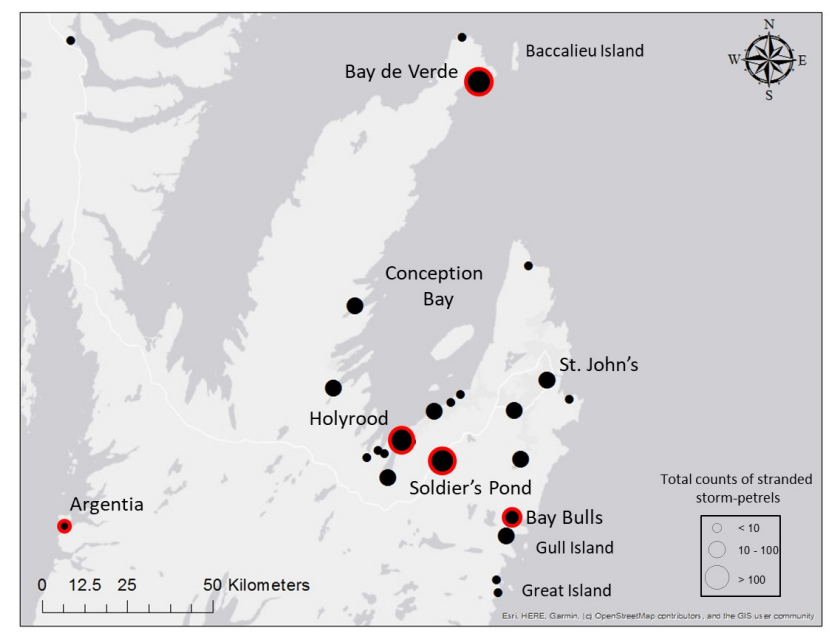

Based on daily searches collected from the Soldier's Pond site in 2018 and 2019 and the Holyrood site in 2019, there appeared to be a lunar influence with the highest strandings occurring around the new moon (moon visibility closest to $0 \%$ ) and few strandings occurring around the full moon (moon visibility closest to $100 \%$; Fig. 7). Our preliminary results also seem to indicate that nights with the highest total strandings tended to coincide with winds blowing from a northern direction (NW to NE) but were not associated with high wind speeds. Mean nightly wind speeds in both years fell within the Beaufort Wind Scale categories of light and gentle breeze (up to $19 \mathrm{~km} / \mathrm{hr}$ ) with only two nights in 2018 reaching mean wind speeds of 20 and $29 \mathrm{~km} / \mathrm{hr}$, categorized as moderate and fresh breeze, respectively (Fig. 7).

Mean annual body mass of fledgling storm-petrels measured from four sites ranged between 45.3 and $54.0 \mathrm{~g}$, with birds stranded in Argentia appearing to have the lowest mass (but note low sample sizes) and birds stranded in Bay de Verde having the highest mass in both years (Table 3 ). We found annual and location differences in mass where sufficient data were collected in both years (Bay de Verde and Holyrood) showing that independent of location, birds stranded in 2018 were heavier compared to $2019\left(\mathrm{~F}_{1,380}=13.15, \mathrm{p}<0.001\right)$ and birds stranded in Bay de Verde were significantly heavier compared to birds stranded in Holyrood across years $\left(\mathrm{F}_{1,380}=42.291, \mathrm{p}<0.001\right.$; Table 3). Mean wing length ranged between 155.5 and $160.3 \mathrm{~mm}$ with no significant differences observed between sites or years (Table 3).
Fig. 7. Reported strandings of Leach's Storm-Petrels (Oceanodroma leucorhoa) in relation to moon visibility (\%) at Soldier's Pond and Holyrood in 2018 and 2019. Hatched bars represent nights with a northern wind direction (NW to NE). Numbers over bar represent mean nightly wind speed $(\mathrm{km} / \mathrm{hr})$.
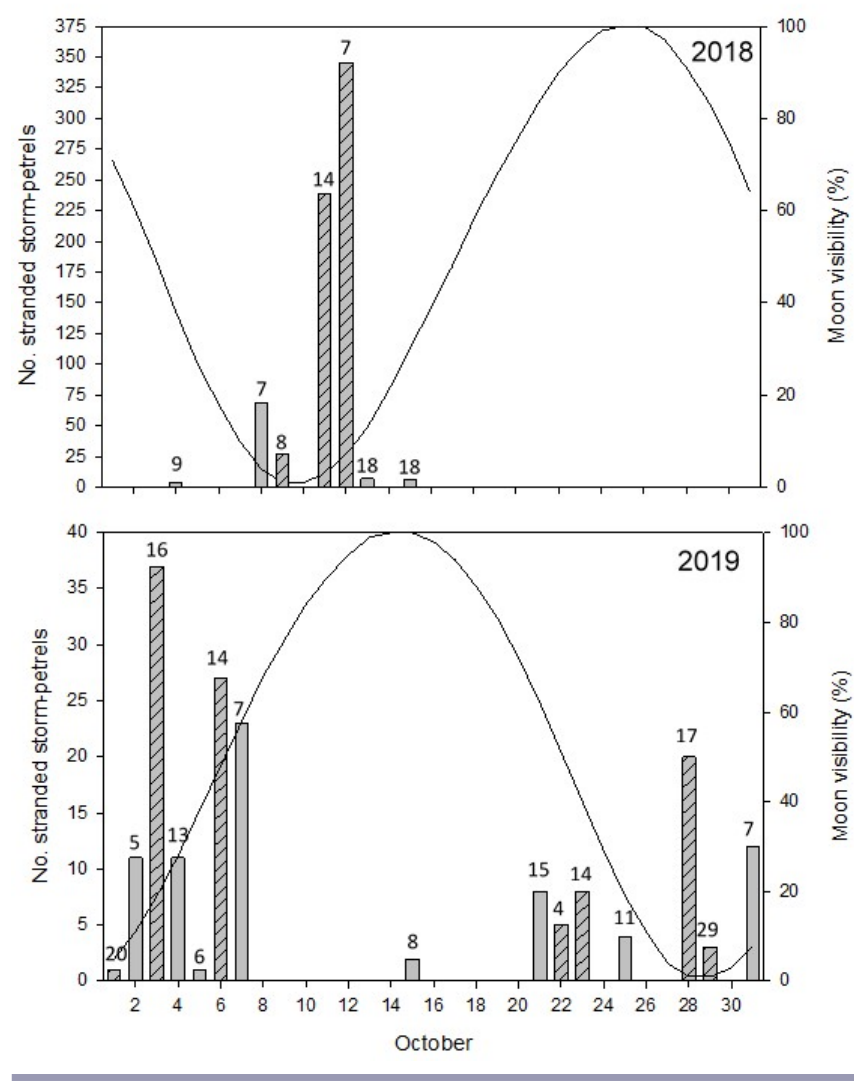

Table 3. Mean ( \pm SD), mass $(\mathrm{g})$, and wing length $(\mathrm{mm})$ of stranded recently fledged Leach's Storm-Petrels (Oceanodroma leucorhoa) recovered from four industry sites in Newfoundland.

\begin{tabular}{lcccccccc}
\hline \hline & \multicolumn{3}{c}{2018} & & & \multicolumn{2}{c}{2019} \\
\cline { 2 - 4 } & Mass & $\begin{array}{c}\text { Wing } \\
\text { length }\end{array}$ & $\mathrm{N}$ & & Mass & $\begin{array}{c}\text { Wing } \\
\text { length }\end{array}$ & $\mathrm{N}$ \\
\hline Argentia & $46.3 \pm 5.3$ & $159.5 \pm 2.1$ & 2 & & $45.3 \pm 4.9$ & $158.2 \pm 5.3$ & 5 \\
Bay de Verde & $54.0 \pm 4.9$ & $158.1 \pm 2.7$ & 11 & & $49.8 \pm 4.1$ & $155.5 \pm 4.1$ & 43 \\
Soldier's Pond & $47.5 \pm 4.3$ & $158.2 \pm 3.4$ & $174 / 176$ & & $47.9 \pm 2.7$ & $160.3 \pm 2.1$ & 3 \\
Holyrood & $47.7 \pm 3.9$ & $157.4 \pm 3.6$ & $248 / 247$ & & $46.4 \pm 4.8$ & $158.5 \pm 3.7$ & 79 \\
\hline
\end{tabular}

\section{DISCUSSION}

\section{Seasonal timing of Atlantic Puffin strandings and the influence of the phase of the moon}

Based on the earliest and latest date when stranded puffins were found between 2011 and 2020, the fledging period of Atlantic Puffins breeding in the Witless Bay Ecological Reserve is restricted 
to a one-month period (6 August to 6 September) with peak fledging occurring during the third week of August. The number of puffins found per night was strongly influenced by the phase of the moon, with the fewest birds found during the two-week period around the full moon. This confirms our previous finding that puffin strandings are related to the moon cycle (Wilhelm et al. 2013), a phenomenon also observed in other bird species that fledge or are otherwise active at night (Verheijen 1981, Telfer et al. 1987, Le Corre et al. 2002, Rodríguez and Rodríguez 2009, Rodríguez et al. 2014, Rodríguez et al. 2016, Cianchetti-Benedetti et al. 2018). The general finding regarding the lack of bird strandings around the full moon is explained by: 1) an innate antipredator mechanism, whereby nocturnal birds have adapted to be less active around the period of the full moon to avoid predation, and 2) the full moon providing natural ambient light to reduce the attraction of artificial lights (reviewed in Rodríguez and Rodríguez 2009, Cianchetti-Benedetti et al. 2018). We did find a general decline in the number of stranded birds as moon visibility increased, which provides support to the latter hypothesis. However, as pointed out by Rodríguez et al. (2017b), these two hypotheses are not mutually exclusive, and therefore are difficult to tease apart without additional research. For example, investigating departure rates of fledglings at the colony at peak fledging and during the various phases of the moon would provide insight on whether puffins avoid fledging around the full moon.

\section{How representative are stranded Atlantic Puffins compared to the local population?}

Our ten-year study revealed that the annual mean body mass of recently fledged puffins is highly variable, with the lowest mean mass of $210 \mathrm{~g}$ observed in 2011 and the highest mean mass of 279 g observed in 2017, a range which includes the mean fledging mass of $260 \mathrm{~g}$ previously reported for Great Island in 1968 and 1969 (Nettleship 1972). We also observed variability in body mass of chicks measured on Gull Island from 2017-2019 with mass being highest relative to their body size in 2017 compared to the other two years.

A three-year study investigating the growth of puffin chicks in relation to food availability on Gull Island revealed that chicks gained more mass per day in 2012 compared to 2011 and 2013, which in turn was related to the availability of their main prey, capelin (Mallotus villosus; Fitzsimmons et al. 2017). These results are consistent with the pattern observed in this study where the mean mass of stranded puffins recovered in 2012 was overall higher compared to 2013 and 2011. The lowest mean annual fledging mass reported in this study coincided with a large mortality event observed on both Gull Island and Great Island in 2011 where hundreds of chicks, many close to fledging, were found dead at the mouth of their burrow (SIW personal observation). In addition to food availability deemed to be poor for puffins breeding in Witless Bay in 2011 (Fitzsimmons et al. 2017), this unprecedented mortality event was attributed to an extended period of unusual cold and wet conditions in August, causing chicks to succumb to hypothermia (Wilhelm et al. 2013). This breeding failure was also reflected in very few numbers of fledglings being found during the first year of the rescue campaign in 2011, despite high search efforts (Wilhelm et al. 2013). Conversely, the highest number of puffins found stranded annually during the course of this study occurred in 2014 and
2017, which were also the two years with the highest mean body mass.

Combined, our results suggest that mean annual variability in fledging mass of stranded birds is sensitive enough to differentiate between favorable and unfavorable local breeding conditions. Furthermore, we observed a strong positive relationship between the total numbers of pufflings found during the fledging season and mean annual body mass of fledglings. Assuming that search effort is relatively constant across years, our results suggest that both the number of fledglings found through efforts of the rescue campaign as well as mean annual body mass of fledglings are representative of local breeding conditions, which in turn may be used as an index to monitor the relative productivity of the local breeding population without causing additional disturbance at the colony.

\section{Assessing the impact of light attraction on the local Atlantic Puffin breeding population}

Using two independent approaches to estimate stranding rates, our results suggest that $<0.2 \%$ of chicks fledging from local breeding colonies are impacted by light pollution emitted from coastal communities. The stranding rate based on recovering birds banded on the colony assumes that all banded chicks successfully fledged from the colony, which if not true would increase the estimated stranding rate. The high fledging success of hatched chicks reported in this study for $2019(0.95)$ suggests that most banded chicks would have successfully departed the colony. However, both approaches also assume that all stranded puffins are found during the nightly searches of the rescue campaign. As discussed in Rodríguez et al. (2017b), accurately estimating the number of stranded fledglings relies on numerous factors, including but not limited to: the extent of the impacted area, search effort, probability of birds being found, persistence of stranded birds, reporting rates of stranded birds, and public awareness to search for and report stranded birds. Many aspects of the rescue campaign in this study lend to increasing the likelihood of reporting stranded puffins, such as: covering a large geographic area that extends along the entire coastline bordering the four puffin colonies within the Ecological Reserve, ensuring consistent nightly search efforts by coordinating the hundreds of volunteers who participate every year, and delivering a comprehensive outreach and education program on the local and online stage to promote searching and reporting. However, evaluating the magnitude of other factors such as the probability of finding a stranded puffin or how long they persist after becoming stranded are unknown and require future research.

While the overall impact to the puffin population appears to be low, a recent review of land-based strandings related to artificial light ranked Atlantic Puffins as the third highest affected species in the world, with all strandings reported from Newfoundland (Rodríguez et al. 2017b), although strandings of fledglings also occur in Iceland (E. Hansen personal communication.). The high volume of stranded birds observed along the coast of the Witless Bay Ecological Reserve is clearly a function of the close proximity of communities $(<3 \mathrm{~km})$ to the two largest colonies in North America, emphasizing the need to move beyond outreach and education, and investigate the effectiveness of different light characteristics to reduce attraction, as well as actively implement and enforce conservation actions (e.g., light minimization and 
shielding during the fledging period) that will minimize strandings in high illuminated areas (Rodríguez et al. 2019). However, the finding that puffins fledging from burrows located on the side of the Gull Island facing the coastal communities, or onshore side, may be at greater risk of being stranded compared to chicks fledging from the offshore side suggests that the orientation of the breeding slope in addition to the proximity of the breeding colony to artificial light sources (Rodríguez et al. 2015) are both important factors to consider when assessing impact. Finally, even though most puffins were found alive and successfully released, the long-term fate of these individuals is unknown. Despite the large number of puffins banded through the rescue campaign since 2011, only one has been re-sighted to date (P.-P. Bitton personal communication). This low encounter rate is associated with the large size of breeding colonies in the Witless Bay Ecological Reserve in which they are likely to recruit (Harris 1983), making it logistically difficult to assess post-fledging survival using a traditional banding approach. Future research should explore the use of tracking devices (e.g., Global Positioning System units with automatic download) to compare the fate of stranded puffins to those that successfully fledge from the breeding colony.

\section{Factors influencing Leach's Storm-Petrel strandings in Newfoundland}

Despite bordering two of the largest Leach's Storm-Petrel colonies in Newfoundland, this species was rarely observed stranded in Witless Bay or surrounding communities, with the exception of the stranding incident on the seismic vessel in Bay Bulls, an adjacent community to Witless Bay. Most stranded birds were reported along the coast of Conception Bay and outside of the brightly lit St. John's metropolitan area. Baccalieu Island, hosting the world's largest Leach's Storm-Petrel colony (Wilhelm et al. 2020), is located at the mouth of Conception Bay, and is the most likely source of reported stranded storm-petrels based on its close proximity to some of the stranding locations and prevailing northerly winds observed on nights when strandings occurred at sites monitored in 2018 and 2019. Storm-petrels are vulnerable to being pushed onshore following gales and storms during their migration period (Teixeira 1987, Pollet et al. 2020). However, neither strong nor persistent winds were observed during the course of this study. It is possible that fledglings leaving Baccalieu Island for the first time mistake Conception Bay as the open ocean and once they reach the bottom of the bay, if not attracted to artificial light sources along the way, continue to travel over land to find the open ocean again. Alternatively, northern onshore winds may push some fledglings into the bay if the strength of their wings is not yet sufficient to allow them to fly against or crosswind, although strandings also occurred during nights when winds were blowing from the south.

Similar to other Procellariformes and puffins, the phase of the moon appears to affect storm-petrel stranding rates, with strandings less likely to occur around the full moon (Verheijen 1981, Telfer et al. 1987, Le Corre et al. 2002, Rodríguez and Rodríguez 2009, Miles et al. 2010, Wilhelm et al. 2013, Rodríguez et al. 2016, Cianchetti-Benedetti et al. 2018, this study). Again, further research is required to differentiate whether this is due to the anti-predatory hypothesis (i.e., storm-petrels refrain from fledging around the full moon to avoid predation) or if moon illumination around the full moon is strong enough to counter the attraction to artificial light.

Strandings that occurred in Bay de Verde, the community adjacent to Baccalieu Island, were attributed primarily to large numbers of live storm-petrels becoming stranded on fishing vessels at night, presumably when vessels steamed by Baccalieu Island coming into port to offload their catch; stranded birds would subsequently fly toward the bright lights of the fish plant from the vessels (S. Green, fisheries observer personal communication). Storm-petrels are known to strand in coastal and offshore waters off Newfoundland on vessels associated with multiple types of industries (e.g., fishing, cargo, cruise, oil and gas exploration and production; Ellis et al. 2013, Gjerdrum, Ronconi, Turner, and Hamer unpublished manuscript, SIW personal observation). The dramatic impacts that vessels can have on seabirds while steaming through important bird areas at night is certainly not novel (see Dick and Donaldson 1978), but unfortunately, remains largely undocumented and difficult to evaluate (Merkel and Johansen 2011). Future studies need to incorporate systematic monitoring of birds stranded on vessels and other at-sea platforms during the breeding season to assess the vulnerability and impact of strandings on breeding adults as well as fledglings.

We documented that storm-petrels regularly become stranded, sometimes by the hundreds in a single night, at industrial sites which require structures and buildings to be well-lit for the safety of employees who work at night, who in turn are also able to look for stranded birds. Hence, the large number of stranded birds at these sites may be a function of light intensity and search effort. Nonetheless, these observed stranding rates remain underestimates as grounded storm-petrels face the threat of depredation by various predators, including gulls, cats, foxes, and mink (T. Smith personal communication, PCR, SMD, and EPC personal observation).

\section{Age and body mass of stranded Leach's Storm-Petrels}

Of the 686 stranded Leach's Storm-Petrels we examined, all but five were aged as recently fledged birds. Fledglings recovered from Bay de Verde were significantly heavier compared to birds recovered $80 \mathrm{~km}$ further away in Holyrood. Although necropsies conducted on a subset of birds stranded in Holyrood in 2018 showed these fledglings to be in excellent condition with high levels of internal fat (Krug et al. 2021), the lower body mass of birds that traveled to the head of the bay may not have fledged the same night of their stranding. Rather, these young stormpetrels may have been unsuccessfully searching for food in the bay for at least a day before stranding. Feeding conditions in Conception Bay are likely not ideal for storm-petrels; breeders on Baccalieu Island travel hundreds of kilometers offshore to forage over the continental shelf on abundant small fish, primarily bioluminescent lantern-fish (family Myctophidae), a deep-water fish that migrates to the surface at night (Hedd and Montevecchi 2006, Hedd et al. 2009, Hedd et al. 2018). Alternatively, the loss of body mass may be a natural phenomenon for all fledglings while they learn to forage on their own.

Other studies have also shown that the majority of stranded birds found on land tend to be newly fledged birds, particularly when strandings occur near breeding colonies (Imber 1975, Telfer et al. 
Avian Conservation and Ecology 16(1): 12 http://www.ace-eco.org/vol16/iss1/art12/

1987, Poot et al. 2008, Rodríguez and Rodríguez 2009, Miles et al. 2010, Rodríguezet al. 2015, Rodríguez et al. 2017b,c). However, over the course of two nights (28-29 September 2019), 37 stormpetrels were found stranded on a docked seismic vessel in Bay Bulls, impacting adults. Based on their body mass, these adult birds were most likely breeders (the mass of breeders later in the breeding season is lower compared to earlier in the breeding season and lower compared to recently fledged storm-petrels; Pollet et al. 2020, Krug et al. 2021), possibly originating from the nearby Witless Bay colonies.

\section{Management implications and future research}

Although the overall impact of light pollution on the local puffin breeding population appears low, supported with a general increasing puffin breeding population in Newfoundland (Wilhelm et al. 2015, Wilhelm 2017), large numbers of recently fledged puffins are nonetheless stranded annually causing unnecessary stress and harm. Fortunately, the majority of puffins are found alive and successfully released, emphasizing the need to maintain a well-coordinated rescue campaign that promotes the reporting of stranded birds and raises awareness regarding the effects of light pollution on fledging seabirds. The impact of land-based light pollution on the Leach's Storm-Petrel population is difficult to assess with our current information. The numbers reported in this study likely vastly underrepresent the actual magnitude, given the large geographic area in which strandings occur coupled with storm-petrels' small size and dark plumage making them harder to find (Rodríguez et al. 2017b). Furthermore, the episodic nature of mass stranding events is also problematic for monitoring, detection, and assessing impact. For both species, there is an urgent need to investigate whether changing light characteristics (e.g., intensity, wavelength) of required lighting would reduce stranding rates as has been documented in other avian species (Salamolard et al. 2007, Poot et al. 2008, Rodríguez et al. 2017a, Rebke et al. 2019). Furthermore, understanding what intrinsic factors lead to the behavior of seabirds flying toward illuminated coastal and inland sites is integral for effective mitigation. A recent study showed that the visual development of Leach's Storm-Petrel chicks is delayed compared to other avian species and their own olfactory development, likely as an adaptation of being reared in a dark burrow where accurate vision is not required for immediate survival and their ability to focus does not appear to be fully developed until after they have fledged (Mitkus et al. 2018). This suggests their vision is compromised during their maiden voyage, perhaps causing them to become more easily disoriented or blinded by artificial lights and collide with structures or the ground (Rodríguez et al. 2017b). The vision development of Atlantic Puffin chicks may be similarly compromised. However, the striking difference in stranding rates along the coast bordering the Witless Bay Ecological Reserve may suggest that both species have different thresholds with respect to artificial light sensitivities, perhaps as a result of their different life history traits, and warrants further investigation. Finally, the use of remote monitoring technology (e.g., radar) would vastly improve our understanding of how fledglings disperse from the colony under varying environmental conditions and how light attraction influences their movements as they transition from coastal islands to the offshore.
Responses to this article can be read online at: https://www.ace-eco.org/issues/responses.php/1809

\section{Acknowledgments:}

We are extremely grateful to the numerous Puffin and Petrel Patrol volunteers for diligently searching for and rescuing stranded seabirds in communities bordering the Witless Bay Ecological Reserve, and across Newfoundland, over the past decade. Special mentions go to Juergen and Elfie Schau, the founders of the Puffin and Petrel Patrol, and Sherry Green, our storm-petrel champion in Bay de Verde. We are very appreciative to Marina Montevecchi for her onsite support to Sherry Green in 2019, to Tracy Smith and Nancy Whittle for coordinating daily searches of storm-petrels at the industrial sites in Holyrood and Soldier's Pond, and to Bill Montevecchi for sharing additional stranding information from Bay de Verde in 2019 and reviewing a previous draft of this manuscript. We also wish to extend a tremendous thank you to the various boat tour operators for assisting in the release of puffin fledglings by boat and are especially grateful to O'Brien's Boat Tours for the use of their facility as the rescue campaign headquarters since 2017. We are indebted to the amazing crew who made the 2019 puffin banding blitz a tremendous success, including: Marina Montevecchi, Josh Cunningham, Dena Wiseman, Jordan Wight, Pierre-Paul Bitton, Sydney Collins, and April Griffin. Birds were collected under Canadian Wildlife Service scientific permit no. SS2505, SC4020, SC4025, SC2014, and SC4044 and banded under Environment and Climate Change Canada Scientific Permit to Capture and Band Migratory Birds no. 10559 X and 10559 AL. Financial and logistic support were provided by Environment and Climate Change Canada's EcoAction Community Funding Program (2011-2013), TD Friends of the Environment (2015), Habitat Stewardship Program for Species at Risk (2015-2017), Nature Canada (2017), the Environmental Damages Fund (2019-2020), Canadian Parks and Wilderness Society - Newfoundland and Labrador Chapter, and Environment and Climate Change Canada's Canadian Wildlife Service. Finally, we would like to thank one anonymous reviewer for providing constructive comments on a previous version of this manuscript.

\section{LITERATURE CITED}

BirdLife International. 2018a. Fratercula arctica. The IUCN Red List of Threatened Species 2018: e.T22694927A132581443. https://doi.org/10.2305/IUCN.UK.2018-2.RLTS.T22694927A132581443. en

BirdLife International. 2018b. Hydrobates leucorhous. The IUCN Red List of Threatened Species 2018: e.T132438298A132438484. https://doi.org/10.2305/IUCN.UK.2018-2.RLTS.T132438298A132438484. en

Cianchetti-Benedetti, M., P. Becciu, B. Massa, and G. Dell'Omo. 2018. Conflicts between touristic recreational activities and breeding shearwaters: short-term effect of artificial light and sound on chick weight. European Journal of Wildlife Research 64:10. https://doi.org/10.1007/s10344-018-1178-x

Cinzano, P., F. Falchi, and C. D. Elvidge. 2001. The first World Atlas of the artificial night sky brightness. Monthly Notices of the 
Royal Astronomical Society 328:689-707. https://doi.org/10.1046/ j.1365-8711.2001.04882.x

Depledge, M. H., C. A. J. Godard-Codding, and R. E. Bowen. 2010. Light pollution at sea. Marine Pollution Bulletin 60:1383-1385. https://doi.org/10.1016/j.marpolbul.2010.08.002

Dick, M. H., and W. Donaldson. 1978. Fishing vessel endangered by Crested Auklet landings. Condor 80:235-236. https://doi. org/10.2307/1367924

Ellis, J. I., S. I. Wilhelm, A. Hedd, G. S. Fraser, G. J. Robertson, J.-F. Rail, M. Fowler, and K. H. Morgan. 2013. Mortality of migratory birds from marine commercial fisheries and offshore oil and gas production in Canada. Avian Conservation and Ecology 8(2):4 https://doi.org/10.5751/ACE-00589-080204

Falchi, F., P. Cinzano, D. Duriscoe, C. C. M. Kyba, C. D. Elvidge, K. Baugh, B. A. Portnov, N. A. Rybnikova, and R. Furgoni. 2016. The new world atlas of artificial night sky brightness. Advancement of Science. https://doi.org/10.1126/sciadv.1600377

Fitzsimmons, M. G., M. E. Rector, D. W. McKay, and A. E. Storey. 2017. High growth and low corticosterone in foodsupplemented Atlantic puffin, Fratercula arctica, chicks under poor foraging conditions. Marine Ecology Progress Series 565:217-226. https://doi.org/10.3354/meps11999

Government of Newfoundland and Labrador. 1994. Management Plan Witless Bay Ecological Reserve. Parks and Natural Areas Division, Department of Environment and Conservation. [online] URL: https://www.gov.nl.ca/ffa/files/publications-parkswitless-bay-ecological-reserve.pdf

Harris, M. P. 1983. Biology and survival of the immature Puffin Fratercula arctica. Ibis 125:56-73. https://doi.org/10.1111/ j.1474-919X.1983.tb03083.X

Harris, M. P., and T. R. Birkhead. 1985. Breeding ecology of the Atlantic Alcidae. In The Atlantic Alcidae: Evolution, Distribution and Biology of the Auks Inhabiting the Atlantic Ocean and Adjacent Water Areas (D. N. Nettleship and T. R. Birkhead, Editors), Academic Press, London, United Kingdom. pp. 156-204.

Harris, M. P., and S. Wanless. 2011. The puffin. T. and A. D. Poyser, London.

Hedd, A., and W. A. Montevecchi. 2006. Diet and trophic position of Leach's storm-petrel Oceanodroma leucorhoa during breeding and moult, inferred from stable isotope analysis of feathers. Marine Ecology Progress Series 322:291-301. https://doi. org/10.3354/meps322291

Hedd, A., W. A. Montevecchi, G. K. Davoren, and D. A. Fifield. 2009. Diets and distributions of Leach's storm-petrel (Oceanodroma leucorhoa) before and after an ecosystem shift in the Northwest Atlantic. Canadian Journal of Zoology 87:787-801. https://doi.org/10.1139/Z09-060

Hedd, A., I. L. Pollet, R. A. Mauck, C. M. Burke, M. L. Mallory, L. A. McFarlane Tranquilla, W. A. Montevecchi, G. J. Robertson, R. A. Ronconi, D. Shutler, S. I. Wilhelm, and N. M. Burgess. 2018. Foraging areas, offshore habitat use, and colony overlap by incubating Leach's storm-petrels Oceanodroma leucorhoa in the Northwest Atlantic. PloS ONE 13(5):e0194389. https://doi. org/10.1371/journal.pone.0194389
Hölker, F., C. Wolter, E. K. Perkin, and K. Tockner. 2010. Light pollution as a biodiversity threat. Trends in Ecology and Evolution 25(12):681-682. https://doi.org/10.1016/j.tree.2010.09.007

Imber, M.J. 1975. Behaviour of petrels in relation to the moon and artificial lights. Notornis 22:302-306.

Krug, D. M., R. Frith, S. N. P. Wong, R. A. Ronconi, S. I. Wilhelm, N. J. O'Driscoll, and M. L. Mallory. 2021. Marine pollution in fledged Leach's storm-petrels (hydrobates leucorhous) from Baccalieu Island, Newfoundland and Labrador, Canada. Marine Pollution Bulletin 162. https://doi.org/10.1016/j.marpolbul.2020.111842

Le Corre, M., A. Ollivier, S. Ribes, and P. Jouventin. 2002. Lightinduced mortality of petrels: a 4-year study from Réunion Island (Indian Ocean). Biological Conservation 105:93-102. https://doi. org/10.1016/S0006-3207(01)00207-5

Merkel, F. R., and K. L. Johansen. 2011. Light-induced bird strikes on vessels in Southwest Greenland. Marine Pollution Bulletin 62:2330-2336. https://doi.org/10.1016/j.marpolbul.2011.08.040

Miles, W., S. Money, R. Luxmoore, and R. W. Furness. 2010. Effects of artificial lights and moonlight on petrels at St Kilda. Bird Study 57:244-251. https://doi.org/10.1080/00063651003605064

Mitkus, M., G. A. Nevitt, and A. Kelber. 2018. Development of the visual system in a burrow-nesting seabird: Leach's storm petrel. Brain, Behavior and Evolution 91:4-16. https://doi. org/10.1159/000484080

Nettleship, D. N. 1972. Breeding success of the Common Puffin (Fratercula arctica L.) on different habitats at Great Island, Newfoundland. Ecological Monographs 42:239-268. https://doi. org/10.2307/1942264

Pinheiro J, D. Bates, S. DebRoy, and D. Sarkar., and R Core Team 2020. nlme: Linear and Nonlinear Mixed Effects Models. R package version 3.1-151. [online] URL: https://CRAN.R-project. org/package $=$ nlme

Pollet, I. L., A. L. Bond, A. Hedd, C. E. Huntington, R. G. Butler, and R. Mauck. 2020. Leach's Storm-Petrel (Oceanodroma leucorhoa), version 1.0 in S. M. Billerman, B. K. Keeney, P. G. Rodewald, and T. S. Schulenberg, editors. Birds of the World. Cornell Lab of Ornithology, Ithaca, NY, USA. https://doi. org/10.2173/bow.lcspet.01

Poot, H., B. J. Ens, H. de Vries, M. A. H. Donners, M. R. Wernand, and J. M. Marquenie. 2008. Green light for nocturnally migrating birds. Ecology and Society 13(2):47. https://doi.org/10.5751/ ES-02720-130247

Pyle, P. 2008. Identification guide to North American birds, Part II. Slate Creek Press, Point Reyes Station, California.

R Core Team. 2020. R: A language and environment for statistical computing. R Foundation for Statistical Computing, Vienna, Austria. [online] URL: https://www.R-project.org/

Rebke, M., V. Dierschke, C. N. Weiner, R. Aumüller, K. Hill, and R. Hill. 2019. Attraction of nocturnally migrating birds to artificial light: the influence of colour, intensity and blinking mode under different cloud cover conditions. Biological Conservation 233:220-227. https://doi.org/10.1016/j.biocon.2019.02.029 
Avian Conservation and Ecology 16(1): 12

Rodríguez, A., J. M. Arcos, V. Bretagnolle, M. P. Dias, N. D. Holmes, M. Louzao, J. Provencher, A. F. Raine, F. Ramírez, B. Rodríguez, R. A. Ronconi, R. S. Taylor, E. Bonnaud, S. B. Borrelle, V. Cortés, S. Descamps, V. L. Friesen, M. Genovart, A. Hedd, P. Hodum, G. R. W. Humphries, M. Le Corre, C. Lebarbenchon, R. Martin, E. F. Melvin, W. A. Montevecchi, P. Pinet, I. L. Pollet, R. Ramos, J. C. Rusell, P. G. Ryan, A. SanzAguilar, D. R. Spatz, M. Travers, S. C. Votier, R. M. Wanless, E. Woehler, and A. Chiaradia. 2019. Future directions in conservation research on petrels and shearwaters. Frontiers in Marine Science 6:94. https://doi.org/10.3389/fmars.2019.00094

Rodríguez, A., G. Burgan, P., Dann, R. Jessop, J. J. Negro, and A. Chiaradia. 2014. Fatal attraction of Short-Tailed Shearwaters to artificial lights. PLOS ONE 9(10):e110114. https://doi. org/10.1371/journal.pone.0110114

Rodríguez, A., A. Chiaradia, P. Wasiak, L. Renwick, and P. Dann. 2016. Waddling on the dark side: ambient light affects attendance behavior of Little Penguins. Journal of Biological Rhythms 31 (2):194-204. https://doi.org/10.1177/0748730415626010

Rodríguez, A., P. Dann, and A. Chiaradia. 2017a. Reducing lightinduced mortality of seabirds: high pressure sodium lights decrease the fatal attraction of shearwaters. Journal for Nature Conservation 39:68-72. https://doi.org/10.1016/j.jnc.2017.07.001

Rodríguez, A., N. D. Holmes, P. G. Ryan, K.-J. Wilson, L. Faulquier, Y. Murillo, A. F. Raine, J. F. Penniman, V. Neves, B. Rodríguez, J. J. Negro, A. Chiaradia, P. Dann, T. Anderson, B. Metzger, M. Shirai, L. Deppe, J. Wheeler, P. Hodum, C. Gouveia, V. Carmo, G. P. Carreira, L Delgado-Alburqueque, C. GuerraCorrea, F.X. Couzi, M. Travers, and M. Le Corre. 2017b. Seabird mortality induced by land-based artificial lights. Conservation Biology 31:986-1001. https://doi.org/10.1111/cobi.12900

Rodríguez , A., J. Moffett, A. Revoltós, P. Wasiak, R. R. McIntosh, D. R. Sutherland, L. Renwick, P. Dann, and A. Chiaradia. 2017c. Light pollution and seabird fledglings: targeting efforts in rescue programs. Journal of Wildlife Management 81:734-741. https://doi.org/10.1002/jwmg.21237

Rodríguez, A., and B. Rodríguez. 2009. Attraction of petrels to artificial lights in the Canary Islands: effects of the moon phase and age class. Ibis 151:299-310. https://doi.org/10.1111/ j.1474-919X.2009.00925.X

Rodríguez, A., B. Rodríguez, Á. J. Curbelo, A. Pérez, S. Marrero, and J. J. Negro. 2012. Factors affecting mortality of shearwaters stranded by light pollution. Animal Conservation 15:519-526. https://doi.org/10.1111/j.1469-1795.2012.00544.x

Rodríguez, A., B. Rodríguez, and J. J. Negro. 2015. GPS tracking for mapping seabird mortality induced by light pollution. Scientific Reports 5:10670. https://doi.org/https://doi.org/10.1038/ srep10670
Rodway, M.S. 1997. Relationship between wing length and body mass in Atlantic puffin chicks. Journal of Field Ornithology 68:338-347

Rodway, M. S., J. W. Chardine, and W. A. Montevecchi. 1998. Intra-colony variation in breeding performance of Atlantic Puffins. Colonial Waterbirds 21:171-184. https://doi.org/10.2307/1521904

Salamolard, M., T. Ghestemme, F.-X. Couzi, N. Minatchy, and M. Le Corre. 2007. Impacts des éclairages urbains sur les petrels de Barau, Pterodroma baraui sur l'Ile de la Réunion et mesures pour réduire ces impacts. Ostrich 78:449-452. https://doi. org/10.2989/OSTRICH.2007.78.2.52.132

Statistics Canada. 2016. Census Profile, 2016 Census. [online] URL: https://www12.statcan.gc.ca/census-recensement/2016/dp$\mathrm{pd} /$ prof/index.cfm?Lang $=\mathrm{E}$

Teixeira, A. M. 1987. The wreck of leach's storm petrels on the Portuguese coast in the autumn of 1983. Ringing and Migration 8:27-28. https://doi.org/10.1080/03078698.1987.9673898

Telfer, T. C., J. L. Sincock, G. V. Byrd, and J. R. Reed. 1987. Attraction of Hawaiian seabirds to lights: conservation efforts and effects of moon phase. Wildlife Society Bulletin 15:406-413.

Verheijen, F. J. 1981. Bird kills at tall lighted structures in the USA in the period 1935-1973 and kills at a Dutch lighthouse in the period 1924-1928 show similar lunar periodicity. Ardea 69:199-203.

Wilhelm, S. 2017. CWS: Waterbird colony database (Atlantic region). Version 1 in OBIS Canada Digital Collections. Bedford Institute of Oceanography, Dartmouth, Nova Scotia, Canada. Published by OBIS, Digital [online] URL: http://www.obis.org/.

Wilhelm, S. I., A. Hedd, G. J. Robertson, P. M. Regular, P. C. Ryan, and R. D. Elliot. 2020. The world's largest breeding colony of Leach's storm-petrel Hydrobates leucorhous has declined. Bird Conservation International 30:40-57. https://doi.org/10.1017/ S0959270919000248

Wilhelm, S. I., J. Mailhiot, J. Arany, J. W. Chardine, G. J. Robertson, and P. C. Ryan. 2015. Update and trends of three important seabird populations in the western North Atlantic using a geographic information system approach. Marine Ornithology 43:211-222.

Wilhelm, S. I., J. J. Schau, E. Schau, S. M. Dooley, D. L. Wiseman, and H. A. Hogan. 2013. Atlantic Puffins are attracted to coastal communities in eastern Newfoundland. Northeastern Naturalist 20:624-630. https://doi.org/10.1656/045.020.0409

Zeileis, A., C. Kleiber, and S. Jackman. 2008. Regression Models for Count Data in R. Journal of Statistical Software 27(8). [online] URL: http://www.jstatsoft.org/v27/i08/.
Editor-in-Chief: Keith A.Hobson Subject Editor: Jean-Pierre L.Savard

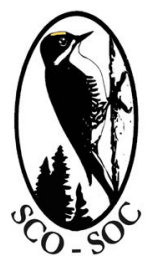

Sponsored by the Society of Canadian Ornithologists and Birds Canada

Parrainée par la Société des ornithologistes du Canada et Oiseaux Canada 